\title{
Melacak Dampak Perubahan Iklim Terhadap Kondisi Makroekonomi dengan Teori Permainan Dinamis
}

\author{
Muhammad Wakhid Musthofa \\ Program Studi Matematika Fakultas Sains dan Teknologi, UIN Sunan Kalijaga, Jl. Marsda Adisucipto \\ No. 1 Yogyakarta, Indonesia \\ Korespondensi; Email: mwakhid_m@yahoo.com
}

\begin{abstract}
Abstrak
Makalah ini membahas tentang model matematika dampak perubahan iklim terhadap kondisi makroekonomi suatu negara. Dengan mengacu pada model pertumbuhan ekonomi endogen pada suatu negara, dengan fungsi output berbentuk fungsi Cobb-Douglas akan diturunkan model matematika yang mendeskripsikan dampak perubahan iklim terhadap kondisi makroekonomi suatu negara. Selanjutnya, akan dikonstruksikan pula fungsi ongkos yang berhubungan dengan model matematika yang telah diturunkan. Mengingat model matematika tersebut masih dalam bentuk sistem persamaan nonlinear, maka diperlukan proses linearisasi untuk menghasilkan model matematika yang linear sehingga memudahkan untuk dianalisis maupun diaplikasikan.
\end{abstract}

Kata Kunci: model matematika; makroekonomi; permainan dinamis; linearisasi

\begin{abstract}
This paper discusses the mathematical model of the impact of climate change on the macroeconomic conditions of a country. By referring to an endogenous economic growth model in a country, with the output function in the form of a Cobb-Douglas function, a mathematical model will be described that describes the effects of climate change on the macroeconomic conditions of a country. Furthermore, it will also construct cost functions related to mathematical models that have been derived. Considering that the mathematical model is still in the form of a nonlinear equation system, a linearisation process is needed to produce a linear mathematical model that makes it easy to analyze and apply.
\end{abstract}

Keywords: mathematical model; macroeconomics; dynamic game; linearization

\section{Pendahuluan}

Perubahan iklim (climate change) merupakan sesuatu yang sulit untuk dihindari dan memberikan dampak terhadap berbagai segi kehidupan. Selama tiga dekade terakhir isu perubahan iklim sudah menjadi salah satu isu utama pada setiap pertemuan internasional. Laporan Intergovernmental Panel on Climate Change (IPCC) 2007 memprediksikan peningkatan suhu bumi rata-rata 2,8 $8^{0}$ selama abad 21 disebabkan oleh meningkatnya konsentrasi $\mathrm{CO}_{2}$. Beberapa hasil studi menunjukkan bahwa perubahan iklim menyebabkan perubahan produktivitas di sektor pertanian, kehutanan, perikanan dan tenaga kerja yang pada akhirnya membawa konsekuensi kepada perubahan kondisi makroekonomi maupun sosial dalam jangka panjang (Zhai Fan, et al. 2009).

Kondisi makroekonomi dipengaruhi oleh banyak hal, salah satunya dikarenakan perkembangan ilmu pengetahuan yang menyisakan banyak ketidakpastian (scientific uncertainties) dalam memprediksi dampak dari perubahan iklim. Studi dari Stern (2006) melaporkan bahwa Pendapatan Domestik Bruto (PDB) global dapat turun sampai 1 persen dan pendapatan perkapita dapat turun hingga 20 persen akibat iklim yang ekstrim. Selain itu, perubahan iklim akibat pemanasan global mempengaruhi sisi permintaan dan penawaran barang dan jasa yang pada gilirannya membawa dampak terhadap perekonomian suatu negara.

Hubungan yang dinamis antara perubahan iklim dan kondisi makroekonomi dapat dideskripsikan dalam framework teori permainan dinamis. Permainan dinamis adalah suatu model matematika yang 
mempelajari situasi yang melibatkan konflik antara dua atau lebih pihak yang berkepentingan untuk mengambil keputusan terbaik dari serangkaian strategi/aksi yang dimungkinkan dengan mempertimbangkan keberadaan berbagai ketidakpastian (uncertainties) yang ada pada situasi tersebut (Engwerda 2005). Penelitian ini akan menganalisis dampak dari perubahan iklim terhadap kondisi makroekonomi di Indonesia dengan metode model permainan dinamis. Penggunaan teori permainan dinamis sebagai metode dalam penelitian ini dimungkinkan karena banyaknya pengambil keputusan yang terlibat dalam masalah ini yang dikombinasikan dengan keberadaan ketidakpastian yang mengiringi keputusan yang diambil.

Metode ini mempunyai kelebihan mampu mengakomodasi perubahan variabel yang begitu cepat, baik variabel perubahan iklim maupun makroekonomi. Keunggulan lainnya adalah dengan bentuk permainan dinamis yang berwujud model matematika maka model ini akan tetap valid untuk jangka waktu yang lama, bahkan mampu digunakan untuk memprediksi bentuk perubahan iklim di masa yang akan datang. Dengan demikian hasil penelitian ini diharapkan dapat dimanfaatkan oleh instansi pemerintah sebagai salah satu rujukan dalam menyusun kebijakan ketahanan pangan nasional dan dalam merumuskan posisi Indonesia dalam forum kerjasama dan perjanjian internasional, khususnya yang terkait dengan masalah perubahan iklim.

\section{Tinjauan Pustaka}

Zhai, et al. (2009) menganalisis mengenai dampak potensial perubahan iklim global jangka panjang terhadap kondisi makroekonomi RRC menggunakan model Computable General Equillibrium (CGE). Hasil penelitian dengan menggunakan sekenario baseline menunjukkan bahwa perubahan iklim akan mengakibatkan penurunan PDB sebesar 1.3 persen dan mengakibatkan welfare loss equivalent sebesar 1.1 persen pada tahun 2080 untuk RRC. Pada tataran global, dampak perubahan iklim diproyeksikan menurunkan PDB riil dunia sebesar 1.4 persen dan mengakibatkan penurunan welfare sebesar 1.3 persen.

Darwin, et al. (1995) melakukan evaluasi dampak perubahan iklim global terhadap makroekonomi dunia dengan suatu model yang menghubungkan antara kondisi iklim terhadap kondisi tanah, sumber daya air, produksi, perdagangan, dan konsumsi 13 komoditi di seluruh dunia. Skenario perubahan iklim yang digunakan didasarkan pada model meteorologi pada Goddard Institute for Space Studies, Geophisical Fuid Dynamic Laboratory, United Kingdom Meteorological Office dan Oregon State University dengan rentang perubahan temperatur global rata-rata 2.8-5.2C dan perubahan curah hujan sebesar 7.8-15.0 persen.

Deressa dan Hassan (2009) melakukan studi menggunakan model Ricardian untuk menangkap adaptasi yang dilakukan petani terhadap keberagaman faktor lingkungan untuk menganalisa dampak perubahan iklim terhadap tanaman pertanian pangan di Ethiopia. Pendekatan Ricardian mengestimasi pentingnya iklim dan variabel lainnya terhadap kapitalisasi nilai lahan pertanian. Penerimaan neto per hektar diregress terhadap variabel iklim dan variabel bebas lainnya. Variabel iklim yang digunakan meliputi temperatur linier dan kuadratik serta curah hujan untuk empat musim: dingin, panas, semi, dan gugur.

Surmaini et al. (2008) yang meneliti mengenai dampak perubahan iklim terhadap produksi padi di tiga daerah dengan ketinggian berbeda yaitu daerah dataran tinggi di Jawa Barat, daerah dataran sedang di Jawa Timur dan dataran rendah di Jawa Tengah menemukan bahwa di dataran rendah kenaikan suhu sampai $2^{0} \mathrm{C}$ dapat menurunkan produktivitas padi hampir 40 persen, sementara di dataran sedang dan tinggi sekitar 20 persen. Hasil penelitian tersebut juga menemukan bahwa penurunan produksi pada tahun 2050 tertinggi terjadi di Kabupaten Bandung yaitu sekitar 65000 ton pada musim hujan dan 50000 ton pada musim kemarau dan terendah di Kabupaten Semarang yaitu sekitar 40000 ton pada musim hujan dan 30000 ton pada musim kemarau.

\section{Model Perubahan Iklim dan Keterkaitannya dengan Kondisi Makroekonomi}

Diberikan model pertumbuhan ekonomi endogen pada suatu negara, dengan fungsi output $Y$ berbentuk fungsi Cobb-Douglas (Tol 2013, Romer 1990, Galor \& Moav 2002) 


$$
Y_{i}(t)=A_{i} \frac{K_{i}^{\alpha_{i}} L_{i}^{\mathcal{K}_{i}} H_{i}^{\beta_{i}}}{P_{i}^{\gamma_{i}}}
$$

Dengan $\alpha_{i}, \beta_{i}, \mathcal{K}_{i} \geq 0, i=1, \cdots N$ dan $Y_{i}(t)$ menyatakan output pertumbuhan ekonomi pada negara ke- $i$. Berikut diberikan arti dari lambang yang digunakan dalam persamaan (1) di atas.

$K_{i}$ : Aset fisik negara ke- $i$

$L_{i} \quad:$ Ketersediaan tenaga kerja efektif negara ke- $i$

$H_{i}$ : Sumber daya manusia negara ke- $i$

$P_{i} \quad$ : Polusi negara ke- $i$

$A_{i}$ : Perkembangan teknologi negara ke- $i$

Polusi secara khusus dimasukkan sebagai faktor yang terpisah dari faktor-faktor yang lain untuk mengakomodasi efek konsentrasi $\mathrm{CO}_{2}$ dalam pertumbuhan ekonomi sebagaimana dilaporkan oleh IPPC (IPPC 2007). Disebabkan sebagian negara mendapatkan keuntungan secara ekonomi dengan keberadaan polusi, maka tanda dari parameter $\gamma_{i}$ pada $P_{i}^{\gamma_{i}}$ tidak harus negatif.

Selanjutnya, akan diturunkan model matematika yang menyatakan kondisi makroekonomi suatu negara akibat terjadinya perubahan iklim. Komponen pemodelan yang akan ditinjau adalah aspek aset fisik, ketersediaan tenaga kerja efektif, sumber daya manusia dan terjadinya polusi.

Pertama, akan diturunkan model matematika yang terkait dengan perubahan aset fisik akibat terjadinya perubahan iklim. Perubahan pada aset fisik pada suatu negara diasumsikan berlangsung secara endogen dan bergantung pada:

1. Investasi,

2. Penyusutan aset, dan

3. Polusi, dengan berpedoman pada pola hubungan bahwa aset fisik berelasi negatif dengan ketersediaan polusi. Pola hubungan ini dinyatakan dengan relasi bahwa aset fisik akan aus jika terdapat lebih banyak polusi dan imbas dari efek katastropik akan meningkat jika ketersediaan polusi juga meningkat.

Dikarenakan kasus dalam pemodelan ini melibatkan banyak negara maka investasi di suatu negara tidak hanya bergantung pada investasi domestiknya, tetapi juga bergantung pada besarnya investasi negara lain. Lebih lanjut, diasumsikan baik investasi domestik maupun nondomestik bergantung pada saving dari negara tersebut. Sehingga didapatkan persamaan

$$
\dot{K}_{l}(t)=\sigma_{i} Y_{i}(t)+\sum_{j \neq i} \sigma_{i j} Y_{j}(t)-\delta_{i} K_{i}(t)-\rho_{i} P_{i}(t)
$$

Dengan $\sigma_{i}, \sigma_{i j}, \delta_{i}, \rho_{i} \geq 0$,

$\sigma_{i}$ : Laju saving aset fisik yang berasal dari investasi domestik negara ke- $i$,

$\sigma_{i j}$ : Laju saving aset fisik yang berasal dari investasi domestik negara ke- $i$ dan negara ke- $j$,

$\delta_{i}$ : Parameter aset fisik negara ke- $i$,

$\rho_{i} \quad$ : Parameter polusi negara ke- $i$.

Selanjutnya, akan diturunkan model matematika yang terkait dengan dinamika ketersediaan tenaga kerja efektif akibat terjadinya perubahan iklim. Diasumsikan ketersediaan tenaga kerja efektif meningkat dengan laju konstan mengikuti persamaan

$$
\dot{L}_{l}(t)=\eta_{i} L_{i}(t), \eta_{i} \geq 0
$$

dengan $\eta_{i}$ menyatakan angka pertumbuhan untuk ketersediaan tenaga kerja efektif. Pada setiap negara, laju pertumbuhan ketersediaan tenaga kerja efektif dapat berbeda.

Berikut ini akan diturunkan model matematika yang terkait dengan dinamika sumberdaya manusia akibat terjadinya perubahan iklim. Akumulasi dari sumber daya manusia adalah endogen. Perubahan sumber daya manusia diasumsikan proporsional terhadap output domestik dan menyusut seiring dengan 
berjalannya waktu. Hal ini sesuai dengan pertimbangan kondisi penuaan yang berdampak pada berkurangnya produktivitas dan progres teknologi yang menggerus generasi tua (Mankiw 1992). Sedangkan pertimbangan bahwa sumberdaya manusia berubah secara proporsional terhadap output domestik adalah untuk kesederhanaan model, yaitu agar tidak terjadi kompleksitas dalam model. Sebagaimana lazim diketahui bahwa sumberdaya manusia pada hakekatnya bergantung pada tingkat pendidikan dan pengalaman kerja. Akan tetapi faktor keluarga juga akan sangat mempengaruhi pengetahuan, ketrampilan, kesehatan, tata nilai yang berlaku di masyarakat, kebiasaan dari anak-anak mereka. Hal inilah yang jika diakomodasi dalam model akan menghasilkan model dengan kompleksitas yang sangat tinggi. Sehingga sumber daya manusia diasumsikan tidak secara langsung berhubungan dengan tingkat pendidikan (Weber 2013). Sebagai gantinya, diasumsikan bahwa sumberdaya manusia bergantung pada pengeluaran negara untuk riset dan pengembangan sumberdaya tersebut. Selanjutnya, untuk mengakomodasi fenomena persaingan sumber daya manusia di era globalisasi diasumsikan akumulasi sumber daya manusia juga bergantung pada level dari sumber daya manusia di luar negeri. Penjelasan di atas menghasilkan persamaan diferensial sumber daya manusia berikut

$$
\dot{H}_{l}(t)=\tau_{i} Y_{i}(t)+\sum_{j \neq i} \tau_{i j} Y_{j}(t)-\omega_{i} H_{i}(t), \tau_{i}, \tau_{i j}, \omega_{i} \geq 0
$$

Terakhir, akan diturunkan model matematika yang terkait dengan pengaruh polusi pada kondisi makroekonomi akibat terjadinya perubahan iklim. Dikarenakan tujuan dari riset ini adalah untuk mengetahui efek jangka panjang polusi yang disebabkan oleh konsentrasi $\mathrm{CO}_{2}$ maka diasumsikan bahwa polusi yang terjadi pada suatu titik di muka bumi akan berdampak pada timbulnya polusi di wilayah yang lain. Dalam model ini diasumsikan polusi dihasilkan dari penggunaan bahan bakar yang bersumber dari fosil $(F)$. Penggunaan teknologi yang lebih efisien di suatu negara akan berakibat pada menurunnya kadar emisi $\mathrm{CO}_{2}$ di negara tersebut dibandingkan dengan negara lainnya. Hal ini diakomodasi dengan keberadaan koefisien $\psi$ pada $F$. Selanjutnya, diasumsikan juga terjadinya penurunan alami polusi seiring dengan berjalannya waktu yang dilambangkan dengan koefisien $\xi$. Perbedaan nilai penurunan alami polusi $\xi$ menunjukkan perbedaan kondisi lingkungan negra tersebut, seperti ketersediaan hutan untuk menurunkan tingkat polusi. Berdasarkan data di atas didapat persamaan berikut

$$
\dot{P}_{l}(t)=\psi_{i} F_{i}(t)+\sum_{j \neq i} \psi_{i j} F_{j}(t)-\xi_{i} P_{i}(t)
$$

dengan $\psi_{i}, \psi_{i j}, \xi_{i} \geq 0$

Selanjutnya, berdasarkan asumsi bahwa fungsi output (1) mempunyai constan return to scale, maka variabel-variabel dalam persamaan (2)-(5) dapat dilakukan penskalaan kembali (rescale) terhadap variabel tenaga kerja efektif. Dengan mengasumsikan $\alpha_{i}+\beta_{i}+\mathcal{K}_{i}-\gamma_{i}=1$ dan dengan mengambil logaritma natural $y_{s i}=\log \left(\frac{Y_{i}}{L_{i}}\right), k_{s i}=\log \left(\frac{K_{i}}{L_{i}}\right), h_{s i}=\log \left(\frac{H_{i}}{L_{i}}\right), p_{s i}=\log \left(\frac{P_{i}}{L_{i}}\right)$ dan $f_{s i}=\log \left(\frac{F_{i}}{L_{i}}\right)$, maka persamaan (1)-(5) dapat ditulis dalam bentuk

$$
\begin{gathered}
y_{s i}=\log \left(A_{i}\right)+\alpha_{i} k_{s i}(t)+\beta_{i} h_{s i}(t)-\gamma_{i} p_{s i}(t), \quad i=1 . . N \\
\dot{k}_{s i}(t)=-\left(\delta_{i}+\eta_{i}\right)+e^{-k_{s i}(t)}\left(\sigma_{i} e^{y_{s i}(t)}+\sum_{j \neq i} \sigma_{i j} e^{y_{s j}(t)+\eta_{j}-\eta_{i}}-\rho_{i} e^{p_{s i}(t)}\right) \\
\dot{h}_{s i}(t)=-\left(\omega_{i}+\eta_{i}\right)+e^{-h_{s i}(t)}\left(\tau_{i} e^{y_{s i}(t)}+\sum_{j \neq i} \tau_{i j} e^{h_{s j}(t)+\eta_{j}-\eta_{i}}\right) \\
\dot{p}_{s i}(t)=-\left(\xi_{i}+\eta_{i}\right)+e^{-p_{s i}(t)}\left(\psi_{i} e^{f_{s i}(t)}+\sum_{j \neq i} \psi_{i j} e^{f_{s j}(t)+\eta_{j}-\eta_{i}}\right)
\end{gathered}
$$


Selanjutnya, dikonstruksikan fungsi ongkos untuk setiap negara $i$ yang harus diminimumkan. Fungsi ongkos dalam hal ini mengandung arti pilihan negara tersebut terhadap sumber energi yang digunakan, yaitu antara energi konvensional yang bersumber dari minyak bumi (fuel energy, $f_{s i}$ ) atau energi yang terbarukan (green energy, $g_{s i}$ ), dengan $g_{s i}=\log \frac{G_{i}}{L_{i}}$. Fungsi ongkos tersebut dinyatakan dengan persamaan

$$
J_{s i}=\int_{0}^{\infty} e^{-\theta_{i} t}\left\{\left(\mu_{i} y_{s i}(t)-\left(f_{s i}(t)+g_{s i}(t)\right)\right)^{2}+\pi_{i} p_{s i}^{2}(t)+r_{i f} f_{s i}^{2}(t)+r_{i g} g_{s i}^{2}(t)\right\} d t, i=1 . . N
$$

Suku pertama pada Persamaan (7) menyatakan kebutuhan energi negara ke- $i$, sedangkan suku kedua menyatakan besarnya polusi yang terjadi pada negara ke- $i$. Parameter $r_{i j}$ menyatakan pilihan relatif negara ke- $i$ dalam menggunakan sumber energinya. Seluruh parameter yang terlibat dalam Persamaan (7) diasumsikan bernilai nonnegatif. Lebih khusus, dimungkinkan parameter $\pi_{i}$ bernilai nol. Fungsi ongkos dalam Persamaan (7) juga menyatakan bahwa nilai fungsi tersebut pada waktu yang akan datang terdiskon secara eksponensial oleh faktor $\theta_{i}$.

Relasi antar variabel dan parameter dalam Persamaan (7) juga memberikan gambaran bahwa keputusan yang telah diambil oleh suatu negara akan memberikan efek tertentu pada variabel-variabel yang dimiliki oleh negara-negara lainnya. Sehingga keputusan suatu negara akan mempengaruhi keputusan yang akan diambil oleh negara yang lain. Hal ini menuntut semua negara yang terlibat untuk bekerja bersama-sama mengelola kondisi makroekonominya agar setiap negara memperoleh nilai fungsi ongkos yang lebih baik.

Dalam tinjauan ilmu matematika gabungan model matematika (1-5) dengan fungsi ongkos (7) membentuk konstruksi permainan dinamis (dynamic game/differential game).

\section{Linearisasi Model}

Untuk keperluan implementasi, model matematika kondisi makroekonomi yang terpengaruh perubahan iklim (1-5) di atas masih buruk. Hal ini dikarenakan model di atas masih berbentuk sistem persamaan yang nonlinear. Menggunakan beberapa operasi aljabar model nonlinear (1-5) berubah menjadi model linear di bawah ini.

$$
\begin{gathered}
y_{i}(t)=\alpha_{i} k_{i}(t)+\beta_{i} h_{i}(t)-\gamma_{i} p_{i}(t), \quad i=1 . . N, \\
\dot{k}_{i}(t)=\tilde{\sigma}_{i}\left(y_{i}(t)-k_{i}(t)\right)+\sum_{j \neq i} \tilde{\sigma}_{i j}\left(y_{j}(t)-k_{i}(t)\right)-\tilde{\rho}_{i}\left(p_{i}(t)-k_{i}(t)\right) \\
\dot{h}_{i}(t)=\tilde{\tau}_{i}\left(y_{i}(t)-h_{i}(t)\right)+\sum_{j \neq i} \tilde{\tau}_{i j}\left(h_{j}(t)-h_{i}(t)\right) \\
\dot{p}_{i}(t)=\tilde{\psi}_{i}\left(f_{i}(t)-p_{i}(t)\right)+\sum_{j \neq i} \tilde{\psi}_{i j}\left(f_{j}(t)-p_{i}(t)\right) .
\end{gathered}
$$

\section{Kesimpulan}

Dalam artikel ini telah diturunkan model matematika (1-5) yang mendeskripsikan pengaruh perubahan iklim terhadap kondisi makroekonomi suatu negara. Linearisasi model juga telah dipaparkan dalam rangka mendapatkan model matematika yang linear (8-11) sehingga mudah untuk dianalisis dan diaplikasikan. Lebih lanjut, fungsi ongkos (7) yang terkait dengan sistem dinamik (1-5) juga telah dikonstruksikan. Dengan demikian telah berhasil dikonstruksikan model permainan dinamis yang menjelaskan dampak perubahan iklim terhadap kondisi makroekonomi suatu negara.

Dalam membahas dampak perubahan iklim terhadap kondisi makroekonomi, artikel ini masih cukup sederhana. Pelacakan dampak perubahan iklim untuk kondisi makroekonomi yang lebih detail menjadi masalah terbuka yang dapat diteliti lebih lanjut. 


\section{Ucapan Terima Kasih}

Penulis mengucapkan terima kasih yang sebesar-besarnya kepada Lembaga Penelitian dan Pengabdian kepada Masyarakat (LPPM) Universitas Islam Negeri (UIN) Sunan Kalijaga atas dana penelitian tahun anggaran 2016 yang telah diberikan sehingga penelitian ini dapat selesai dilaksanakan dan hasil penelitian ini dapat dipublikasikan.

\section{Referensi}

[1] Darwin, R., Marinos, T., Jan, L., dan Anton R. 1995. World Agriculture and Climate Change: Economic Adaptations. Agricultural Economic Reportn no. 703.

[2] Deressa, T.T, dan Hassan, R.M. 2009. Economic Impact of Climate Change on Crop Production in Ethiopia: Evidence from Cross-section Measures. Journal of African Economies, 18 (4): 529-554.

[3] Engwerda, J.C. 2005. LQ Dynamic Optimization and Differential Game, John Wiley \& Sons, Ltd., England.

[4] Galor, O., \& Moav, O. 2002. Natural Selection And The Origin Of Economic Growth, Quaterly Journal of Economics, Vol. 117.

[5] Intergovernmental Panel on Climate Change. 1996. Climate Change 1994. Cambridge University Press, London.

[6] Mankiw, N., Romer, D., dan Weil, D. 1992. A Contribution to The Empirics of Economic Growth, Quaterly Journal of Economics, Vol. 107.

[7] Romer, P. 1990. Endogenous technological change, Journal of Political Economy, Vol. 98.

[8] Stern, N. 2006. Review on the Economics of Climate Change. London School of Economics and Political Sciences.

[9] Surmaini, E., Rakman, dan Boer R. 2008. Dampak Perubahan Iklim Terhadap Produksi Padi: Studi Kasus Pada Daerah Dengan Tiga Ketinggian Berbeda. Balai Besar Penelitian dan Pengembangan Sumberdaya Lahan Pertanian, Badan Litbang Pertanian, Departemen Pertanian, Jakarta.

[10] Tol, R. 2013. Targets for Global Climate Policy: Anoverview. Journal of Economic Dynamics and Control, Vol. 37.

[11] Weber, S. 2013. Human Capital Depreciation And Education Level: An Empirical Investigation, International Journal of Manpower, forthcoming.

[12] Zhai, F., Tun, L., dan B. Enerelt. 2009. A General Equilibrium Analysis of the Impact of Climate Change on Agriculture in the Peoples Republic of China, Asian Development Review, Asian Development Bank, Vol. 26, No.1. 